КРИТИКА БУРЖУАЗНОЙ ИАЕОАОГИИ И РЕВИЗИОНИЗМА

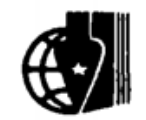




\title{
Ján Lazar
}

\author{
EIGENTUM \\ IN DER \\ BÜRGERLICHEN \\ RECHTSTHEORIE
}

Akademie-Verlag Berlin

1980 


\section{Ян Лазар}

$\mathbf{a}$

\section{СОБСТВЕННОСТЬ \\ В БУРЖУАЗНОЙ ПРАВОВОЙ ТЕОРИИ}


Перевод с немецкого:

В. П. РАССОХИН, кандидат юридических наук (предисловие, введение, гл. гл. I, II, $\$ 1,2$ гл. III)

В. МАРЧЕНКО (§ 3 гл. III, гл. гл. IV, V, заключение)

Специальное научное редактирование и вступительная статья В. А. КИКОТЯ, кандидата юридических наук

Редакционная коллегия серии:

Н. М. КЕИЗЕРОВ, доктор юридических наук, профессор М. Н. МАРЧЕНКО, доктор юридических наук В. А. ТУМАНОВ, доктор юридических наук, профессор

\section{Рецензент}

Ю. К. ТОЛСТОП, доктор юридических наук, профессоD

\section{Лазар Я.}

Л17 Собственность в буржуазной правовой теории: Пер. с нем. - М.: Юрид. лит., 1985. - 192 с. (Критика буржуазной идеологии и ревизионизма).

Автор, известный чехословацкий правовед, на основе марксистского учения о собственности рассматривает различные буржуазные концепцин права собственности. В кннге анализируются буржуазные учения пернода государственно-монополистического капитализма, концепция собственности в идеологии современной соцнал-демократии, а также меры государственного вмешательства в экономическую жизнь, якобы выхмлащивающие, социализнрующие право частной капнталистической собственности.

Для научных работников, преподавателей и аспирантов гуманитарных вузов, пропагандистов.

$$
\text { Л } \frac{1206000000-080}{012(01)-85} 64-85
$$

(C) Akademie-Verlag Berlin 1980

(C) Перевод на русский язык, вступительная статья и примечанчя Издательство «Юридическая литература», 1985 